\title{
CFTR wt Allele
}

National Cancer Institute

\section{Source}

National Cancer Institute. CFT R wt Allele. NCI Thesaurus. Code C111926.

Human CFT R wild-type allele is located in the vicinity of $7 q 31.2$ and is approximately 203 $\mathrm{kb}$ in length. This allele, which encodes cystic fibrosis transmembrane conductance regulator protein, plays a role in the transport of chloride ions. Mutation of the gene is associated with cystic fibrosis and congenital bilateral absence of the vas deferens. 